\title{
Expression of steroidogenic enzymes in porcine polycystic ovaries
}

\author{
Anna Kozłowska1, Mariusz Majewski², Barbara Jana1 \\ ${ }^{1}$ Division of Reproductive Endocrinology and Pathophysiology, Institute of Animal Reproduction and \\ Food Research of the Polish Academy of Sciences, Poland \\ ${ }^{2}$ Department of Human Physiology, Faculty of Medical Sciences, University of Warmia and Mazury, \\ Olsztyn, Poland
}

\begin{abstract}
In the present study the expression pattern of the cholesterol side-chain cleavage cytochrome $\left(\mathrm{P} 450_{\text {scc }}\right), 3 \beta$ hydroxysteroid dehydrogenase $\left(3 \beta\right.$-HSD) and aromatase $\left(\mathrm{P} 450_{\text {arom }}\right)$ was analyzed in the health and polycystic ovaries of gilts by means of the Western blot and immunohistochemistry. The polycystic status of ovaries was induced by i.m. dexamethasone (DXM) injections on days 7-21 of the estrous cycle. Macroscopic observation of ovaries of DXM-treated gilts revealed the presence of cysts $(1-2 \mathrm{~cm}$ in diameter, with a mean number of $7.0 \pm 1.2$ per ovary), a decrease $(\mathrm{P}<0.05)$ in number of small follicles (1-3 mm in diameter), as well as the lack of medium-sized follicles (4-6 mm in diameter) and corpora lutea, as compared to the control animals. The expression of $\mathrm{P} 450_{\text {scc }}(\mathrm{P}<0.01), 3 \beta-\mathrm{HSD}(\mathrm{P}<0.05)$ and $\mathrm{P} 450_{\text {arom }}(\mathrm{P}<0.001)$ proteins in the cysts was higher than in the medium-sized follicles of the control gilts. Moreover, DXM injections resulted also in an enhancement $(\mathrm{P}<0.05)$ in the level of $\mathrm{P} 450_{\text {scc }}$ protein in the walls of small follicles as compared to the control gilts. Following DXM administration the immunoreactivity (IR) of $\mathrm{P} 450_{\text {scc }}$ in the primordial follicles was lower than in the control group. Comparing to the control gilts, the reaction for this enzyme in DXM-treated animals was observed in secondary follicles, while for $3 \beta$-HSD, in primordial, primary, as well as secondary follicles. The immunostaining for P450 (theca cells) and $\mathrm{P} 450_{\text {arom }}$ (granulosa cells) in the small follicles of the DXM-treated gilts were more prominent than those found in the gonads of control animals. However, IR for P450 $\mathrm{scc}_{\mathrm{s}}$ was not found in the granulosa cells of small follicles in the gilts receiving DXM. The intensity of $\mathrm{P} 450_{\text {scc }}$ and $\mathrm{P} 450_{\text {arom }}$ labelling was distinctly enhanced in the cysts as compared to the medium follicles of the control animals. Furthermore, in contrary to the medium follicles of the control animals, faint IR for $3 \beta$-HSD was found in the granulosa cell layer of cysts. Our data revealed that both the expression of $\mathrm{P} 450_{\text {scc }}, 3 \beta$ HSD and $\mathrm{P} 450_{\text {arom }}$ and localization of these enzymes in polycystic ovaries were different from those, found under physiological conditions. These results suggested that above-mentioned enzymes may, by influencing the ovarian steroid synthesis, play an essential role in the creation and/or course of cystic ovarian disease.
\end{abstract}

Key words: cystic ovary, steroidogenic enzymes, gilt

\section{Introduction}

Cystic ovarian disease (COD) is a common reproductive disorder in women and females of domestic animals, leading to temporal or permanent infertility. The etiology and pathogenesis of COD are still obscured. It is generally assumed that cysts are mainly caused by

Correspondence: B. Jana, Division of Reproductive Endocrinology and Pathophysiology, Institute of Animal Reproduction and Food Research of the Polish Academy of Sciences, Tuwima 10, 10-747 Olsztyn, Poland; e-mail: baja@pan.olsztyn.pl disturbances in the function of the hypothalamic-pituitary-ovarian axis, causing impairment of the synthesis, release, and/or storage of various hormones in this functional unit. Stressors may, by activation of the hypothalamic-pituitary-adrenocortical axis, also play an important role in the formation of ovarian cysts. An increase in corticotropin-releasing factor secretion suppresses the activity of hypothalamic gonadotropinreleasing hormone $(\mathrm{GnRH})$ and luteinizing hormone (LH). Moreover, studies conducted in pigs and cows showed that an elevated level of glucocorticoids is able to inhibit the release of GnRH and/or LH, in this way changing ovarian steroidogenesis [1-4]. 
It has previously been reported that alterations in the content of steroid hormones in the cystic ovaries of women $[5,6]$, rat [7] and cow [8] was accompanied by changes in the expression and cellular distribution pattern of cholesterol side-chain cleavage cytochrome $\left(\mathrm{P} 450_{\text {scc }}\right)$, 3 $\beta$-hydroxysteroid dehydrogenase (3 $\beta$ HSD), 17,20-lyase, 20 $\alpha$-HSD and/or aromatase cytochrome (P450 arom $)$. Furthermore, our pilot study showed that dexamethasone (DXM) injections in gilts from day 16 of the first studied estrous cycle until day 9 of the second studied cycle, lead to changes in the of $\mathrm{P} 450_{\text {scc }}, 3 \beta$-HSD and $\mathrm{P} 450_{\text {arom }}$ protein expression, as well as in the content of progesterone $\left(\mathrm{P}_{4}\right)$, androgens and estrogens in ovarian structures [9]. It is generally known that the morphological and functional changes of polycystic ovaries are closely dependent on the phase of estrous cycle, in which the administration of cyst-induced hormones was started [10-12]. Thus, it may be hypothesized that the beginning of DXM treatment in the luteal phase of the estrous cycle may induce the changes in the ovarian morphology and steroidogenic activity, different from those found after induction of cysts formation during the follicular phase of the estrous cycle [9].

Therefore, the present study was aimed at unraveling in detail (1) the $\mathrm{P} 450_{\text {scc }}, 3 \beta$-HSD and $\mathrm{P} 450_{\text {arom }}$ protein expression pattern, and (2) the cellular localization of $\mathrm{P} 450_{\mathrm{scc}}, 3 \beta$-HSD and $\mathrm{P} 450_{\text {arom }}$ in the porcine ovaries with polycystic status, induced by DXM injections on days 7-21 of the estrous cycle.

\section{Materials and methods}

Animals and experimental procedure. The experiment was carried out on 12 crossbred gilts (Large White x Landrace), aged 7-8 months and weighting 90-100 kg, with two controlled subsequent estrous cycles, that were randomly divided into the control (CON, $\mathrm{n}=6)$ and experimental groups (DXM, $\mathrm{n}=6)$. Behavioural estrous was detected by using the boar-tester. The animals were individually housed in stalls, under conditions of natural light and room temperature. They were fed a commercial grain mixture and tap water ad libitum. All experimental procedures followed the principles of the animal care (NIH publication No. 86-23, revised in 1985), as well as the specific national law on animal protection.

In the DXM group, cysts were induced in all animals by i.m. injections of DXM $(3.3 \mu \mathrm{g} / \mathrm{kg}$ of b.w., in total volume of $6 \mathrm{ml}$; Dexasone ${ }^{\circledR}$, Norbrook Laboratory, Newry, UK), every 12 hours from day 7 ( 1 day of the study) to day 21 of the first studied estrous cycle (i.e. by 15 consecutive days). During the same period of time, animals of the CON group were injected with $6 \mathrm{ml}$ of saline. The gilts were slaughtered by electrical shock (ENZ 300 Metalowiec, Bydgoszcz, Poland) and exsanguinated on expected 11 day of the second studied estrous cycle (i.e. on 26 day of the study), and the ovaries were collected. Afterwards, the weight, volume, length, width and height of the gonads were studied, and the number of ovarian structures was estimated. The follicles were divided into two size classes: 1-3 and 4-6 mm in diameter. Follicular structures exceeding $1.0 \mathrm{~cm}$ in diameter were classified as cysts [13]. Samples of follicular and cystic walls and corpora lutea (CL) were shock-frozen in liquid nitrogen and stored at $-80^{\circ} \mathrm{C}$ in order to estimate the expression of $\mathrm{P} 450_{\text {scc }}, 3 \beta-\mathrm{HSD}$ and $\mathrm{P} 450_{\text {arom }}$.
To determine the localization of above-mentioned enzymes by routine single-immunofluorescence technique, fragments of ovaries were fixed by immersion in Zamboni`s fixative for $30 \mathrm{~min}$, washed in $0.1 \mathrm{M}$ phosphate buffer and then stored in $18 \%$ sucrose and then frozen $\left(-80^{\circ} \mathrm{C}\right)$ until sectioning.

Western blotting analysis. The $\mathrm{P} 450_{\mathrm{scc}}, 3 \beta$-HSD and $\mathrm{P} 450_{\text {arom }}$ protein expression in the ovarian structures was estimated with the method described by Jana et al. [14]. Briefly, pieces of follicular and cystic walls, as well as CL (only from animals belonging to the $\mathrm{CON}$ group) were placed in freshly prepared ice-cold homogenization buffer $(50 \mathrm{mmol} / \mathrm{l}$ Tris- $\mathrm{HCl}, \mathrm{pH} 7,4 ; 150 \mathrm{mmol} / \mathrm{l} \mathrm{NaCl}$; $1 \%$ Triton $\mathrm{X}-100,1.5 \mu \mathrm{M} / \mathrm{ml}$ aprotinin, $52 \mu \mathrm{mol} / 1$ leupeptin, 1 $\mathrm{mmol} / 1$ pepstatin A, $1 \mathrm{mmol} / \mathrm{l} \mathrm{EDTA}, 1 \mathrm{~mol} / 1 \mathrm{PMSF}$ ) and fogged for $10 \mathrm{~min}$ at $2500 \times \mathrm{g}$ at $4^{\circ} \mathrm{C}$. Homogenates were then centrifuged for $1 \mathrm{~h}$ at $17500 \times \mathrm{g}$ at $4^{\circ} \mathrm{C}$ and the pellets was stored at $-80^{\circ} \mathrm{C}$ for further analysis. The protein levels were determined by the method of Bradford [15]. The equal amounts $(20 \mu \mathrm{g})$ of membrane fractions were dissolved in sodium dodecyl sulphate (SDS) gel-loading buffer $(50 \mathrm{mmol} / 1$ Tris-HCl, $\mathrm{pH} 6.8 ; 4 \%$ SDS, $20 \%$ glycerol and $2 \% 2$-mercaptoethanol), heated to $95^{\circ} \mathrm{C}$ for 4 min and separated on $10 \%$ SDS-polyacrylamide gel by electrophoresis. Separated proteins were then electroblotted onto $0.45 \mu \mathrm{m}$ nitrocellulose membrane in transfer buffer $(20 \mathrm{mmol} / 1$ Tris, $\mathrm{pH} 8.3 ; 150 \mathrm{mmol} / 1$ glycine, $10 \%$ methanol). The nonspecific binding sites were blocked by shaking with $5 \%$ skim milk for $1.5 \mathrm{~h}$ at room temperature (RT). Next, nitrocellulose membrane were incubated overnight at $4{ }^{\circ} \mathrm{C}$ with the primary antibodies including rabbit antirat $\mathrm{P} 450_{\text {scc }}$ polyclonal antibody (diluted 1:1 000; Chemicon, Temecula, CA, USA), rabbit anti-mouse $3 \beta$-HSD polyclonal antibody (diluted 1:5 000; a gift from Dr. N. Rahman, University of Helsinki, Finland) and rabbit anti-human placental $\mathrm{P} 450_{\text {arom }}$ polyclonal antibody (diluted 1:2 000; provided by Hauptman-Woodward Medical Research Institute, Inc., Buffalo, USA), and then with secondary biotinylated goat anti-rabbit antibody (1:3 000; Vectastain ABC kit; Vector Laboratories, Inc., Burlingame, CA, USA). Reaction product was visualized by incubation with a mixture of 3,3'-diaminobenzidine tetrahydrochloride (DAB, SigmaAldrich Co., USA) and $\mathrm{H}_{2} \mathrm{O}_{2}$ in Tris-buffered saline ( $\mathrm{pH}$ 7.2) for 3 min. The content of the studied enzyme was determined in each tissue during three independent analyses. All immunoblotts were quantitated by scanning on KODAK 1D Image Analysis software (USA). The intensity of bands detected by one-dimensional image analysis was reported as arbitrary units. Data were expressed as a ratio of $\mathrm{P} 450_{\text {scc }}, 3 \beta$-HSD and $\mathrm{P} 450_{\text {arom }}$ proteins relative to $\beta$-actin protein in arbitrary optical density units.

Single-labelling immunofluorescence. Fragments of the ovaries were cut in a cryostat (Reichert-Jung, Nußloch, Germany) into 10$\mu \mathrm{m}$-thick sections and then subjected to routine single-immunofluorescence technique described by Coons [16]. Briefly, sections were incubated in the humid chamber, overnight at RT with antibodies, the same as in Western blotting analyses: rabbit anti-rat $\mathrm{P}_{450}$ scc (diluted 1:500), rabbit anti-mouse 3 $\beta$-HSD (diluted 1:500) and rabbit anti-human placental $\mathrm{P} 450_{\text {arom }}$ (diluted 1:500). Primary antisera were then labelled by species-specific secondary antibodies conjugated to biotin (donkey anti-rat, diluted 1:800) and the latter antisera were then visualized by a streptavidin-CY3 complex (diluted 1:9 000), both from Jackson Immunoresearch, USA. Microscopically, follicles were classified according to developmental stages as primordial, primary, secondary and tertiary $[17,18]$. Additionally, tertiary follicles were divided into two size classes: small (to $3 \mathrm{~mm}$ in diameter) and medium (4-6 $\mathrm{mm}$ in diameter). The diameter of follicles and cysts, as well as the kind of ovarian cells displaying immunoreactivity (IR) for studied enzymes and the intensity of the immunostaining were estimated using Olympus BX51 microscope equipped with epi-fluorescence 
Table 1. Mean ( SEM) weight, volume and measurements of the ovaries, as well as the number of the structural elements in the control gilts (group CON) and animals after DXM injections (group DXM).

\begin{tabular}{|l|c|c|}
\hline \multicolumn{1}{|c|}{ Characteristic } & CON & DXM \\
\hline Weight (g) & $9.8 \pm 0.9$ & $4.3 \pm 0.4^{* *}$ \\
Volume (ml) & $8.0 \pm 0.8$ & $4.3 \pm 0.4$ \\
Measurements (cm): & & \\
length & $4.5 \pm 0.4$ & $3.1 \pm 0.3^{*}$ \\
width & $2.7 \pm 0.2$ & $1.8 \pm 0.2$ \\
height & $3.5 \pm 0.8$ & $1.4 \pm 0.2^{* *}$ \\
\hline Number of follicles in & & \\
diameter (mm): & & \\
$1-3$ & $13.8 \pm 2.4$ & $5.0 \pm 2.6^{*}$ \\
$4-6$ & $7.5 \pm 1.3$ & $1 . \mathrm{s}$. \\
Number of cysts & $1 . \mathrm{s.}$ & $7.0 \pm 1.2$ \\
Number of corpora lutea & $9.3 \pm 1.0$ & $1 . \mathrm{s}$. \\
\hline
\end{tabular}

${ }^{*} \mathrm{p}<0.05 ; *{ }^{*}<0.01$ indicate significant differences between the examined groups, 1.s. - the lack of structure

and appropriate filter sets, as well as a image analysis software (Olympus Microimage) by two independent researches. The results were expressed semi-quantitatively (arbitrary) as strong $(+++)$, high $(++)$, faint $(+)$ or no reactions $(-)$, as described previously by Levanti et al. [19]. This procedure was applied to 16 randomly chosen ovarian sections from each of the animal studied and then pooled and presented as mean value.

Statistical analysis. Student $t$-test was used to compare the mean $( \pm$ SEM) number of the ovarian structures, weight, volume, measurements of ovaries, as well as the intensity of bands staining (arbitrary units) between the CON and DXM group (InStat GraphPad, San Diego, CA).

\section{Results}

\section{Macroscopic evaluation of ovaries}

After injections of the DXM, it has been found that the weight $(\mathrm{P}<0.01)$, length $(\mathrm{P}<0.05)$ and height $(\mathrm{P}<0.01)$ of the gonads decreased, when compared to the values observed in control ovaries (Table 1). DXM-induced cysts, $1-2 \mathrm{~cm}$ in diameter, were found in both ovaries of all the DXM-treated gilts, in mean number of $7.0 \pm 1.2$ per ovary. Moreover, in the cystic-changed ovaries the number of small follicles (1-3 mm in diameter) was lower $(\mathrm{P}<0.05)$ than in the control animals. Furthermore, the medium follicles $(4-6 \mathrm{~mm}$ in diameter) and CL were not present in the ovaries of gilts treated with DXM.

\section{$P 450_{\text {sce }} 3 \beta-H S D$ and $P 450_{\text {arom }}$ protein expression in ovarian structures}

Expression of $\mathrm{P} 450_{\mathrm{scc}}, 3 \beta$-HSD and $\mathrm{P} 450_{\text {arom }}$ proteins was observed at clearly detectable levels in the follicles and CL of the control gilts and in the follicles and
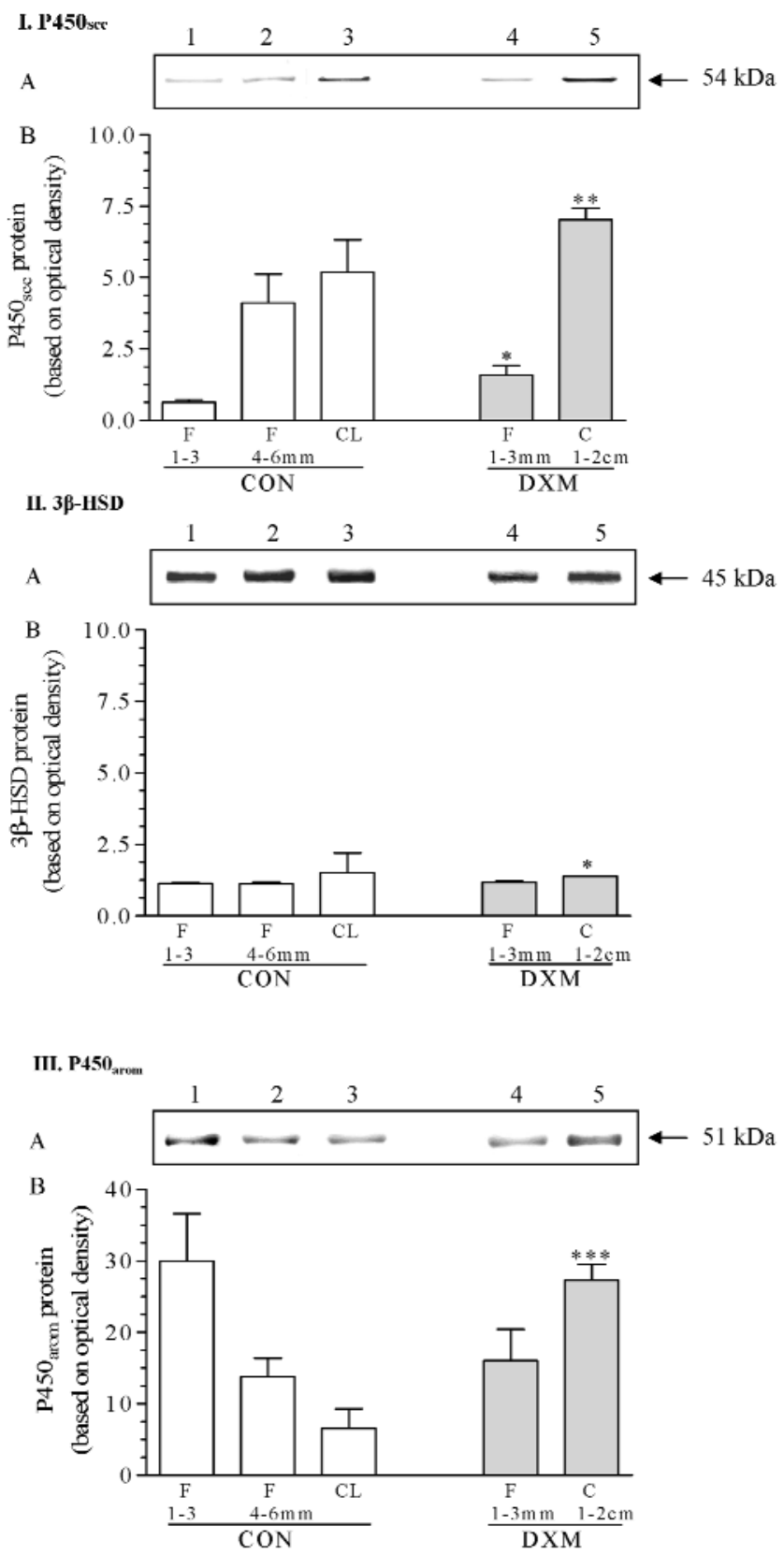

Fig. 1. Western blot of $\mathrm{P} 450_{\text {scc }}$ (I), $3 \beta-H S D$ (II) and $\mathrm{P} 450_{\text {arom }}$ (III) $\mathrm{A} /$ in the follicles $(\mathrm{F})$, corpora lutea $(\mathrm{CL})$ of the control gilts (group $\mathrm{CON}$ ) and in the F and cysts (C) animals after DXM injections (group DXM). Group CON, the 1-3 mm F (line 1), the 4-6 mm F (line 2) and the CL (line 3). Group DXM, the 1-3 mm F (line 4) and the $\mathrm{C}$ (line 5). B/ densitometric analysis of enzymes. Data were expressed as a ratio of $\mathrm{P} 450_{\text {scc }}, 3 \beta$-HSD and $\mathrm{P} 450_{\text {arom }}$ proteins relative to $\beta$-actin protein in arbitrary optical density units. ${ }^{*} \mathrm{p}<0.05 ; * * \mathrm{p}<0.01 ; * * * \mathrm{p}<0.001$ - indicate significant differences between the examined groups.

cysts of the DXM-injected gilts. Expression of $\mathrm{P} 450_{\text {scc }}$ protein in the walls of small follicles collected from the DXM group was higher $(\mathrm{P}<0.05)$ than in the CON group. The $\mathrm{P} 450_{\text {scc }}(\mathrm{P}<0.01), 3 \beta-\mathrm{HSD}(\mathrm{P}<0.05)$ and $\mathrm{P} 450_{\text {arom }}(\mathrm{P}<0.001)$ protein levels in the cystic walls were enhanced compared with the medium follicles of 


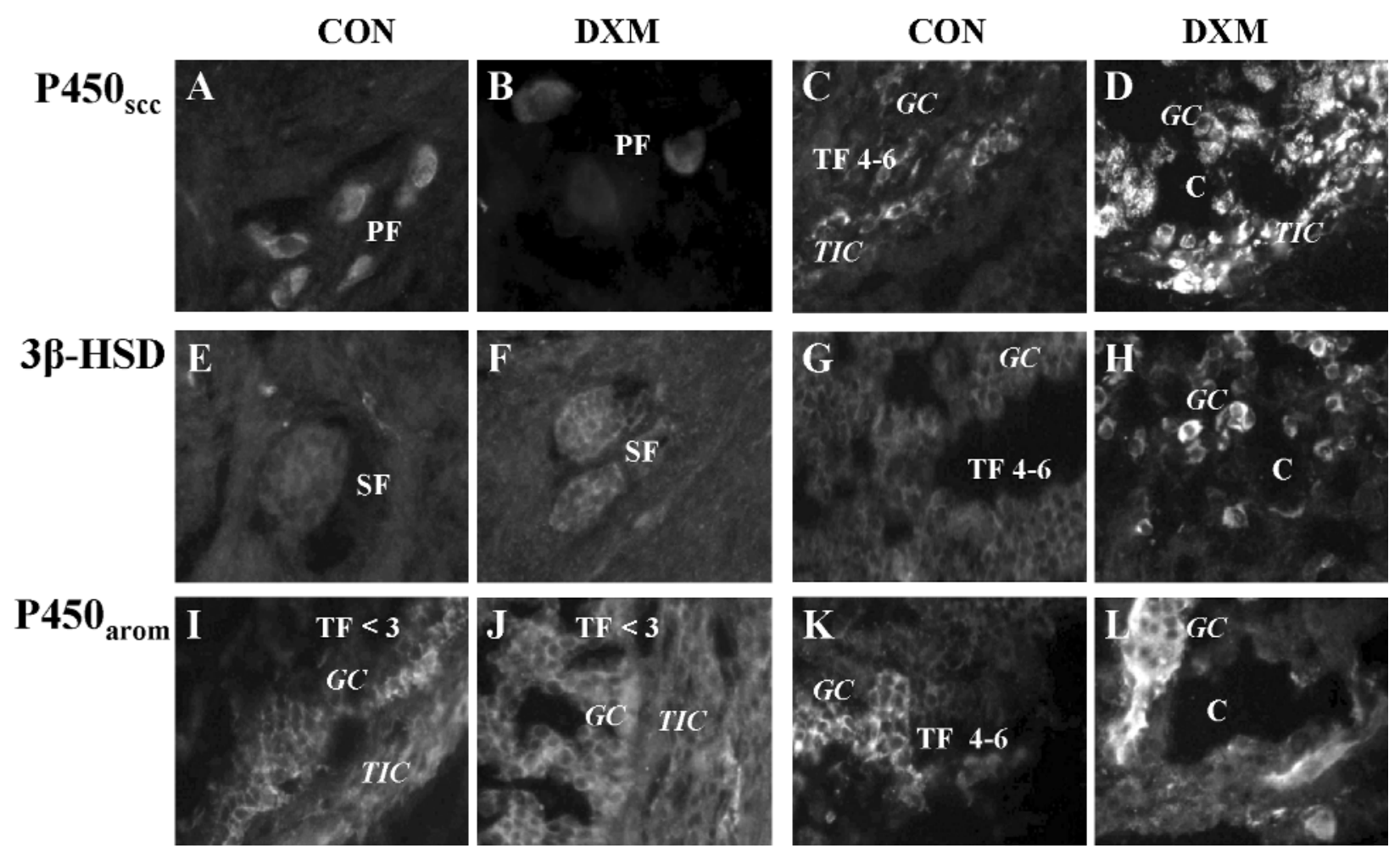

Fig. 2. Localization of $\mathrm{P} 450_{\text {scc }}, 3 \beta-\mathrm{HSD}$ and $\mathrm{P} 450_{\text {arom }}$ in the ovaries of the control gilts (group CON) and animals after DXM injections

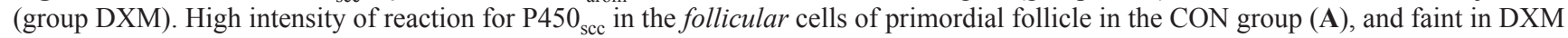

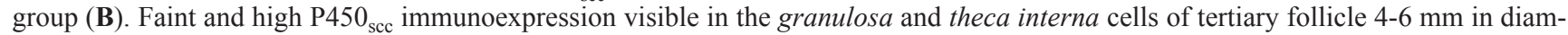
eter of the control gilt, respectively $(\mathbf{C})$, and high in the granulosa and strong in the theca interna layers of cyst (D). Absent of 3 -HSD in the granulosa cells of secondary follicle in the control gilt $(\mathbf{E})$ and faint staining of these cells in the DXM group (F). No immunostaining of $3 \beta$-HSD in the granulosa cells of tertiary follicle 4-6 $\mathrm{mm}$ in diameter of the control animal (G). High reaction for this enzyme visible in the granulosa cells of cyst $(\mathbf{H})$. Faint $\mathrm{P} 450_{\text {arom }}$ staining of the granulosa and theca interna cells in tertiary follicle to 3 mm in diameter of the control gilt (I). High and faint intensity of the reaction in the granulosa and theca interna cells of this follicle in the cystic ovary, respectively $(\mathbf{J})$. High P450 arom staining of the granulosa cells in tertiary follicle 4-6 mm in diameter of the control gilt (K). Note strong intensity of the reaction in the granulosa layer of the cyst $(\mathbf{L})$. PF - primordial follicle, SF - secondary follicle, TF $<3-$ tertiary follicle to $3 \mathrm{~mm}$ in diameter, TF 4-6 - tertiary follicle 4-6 mm in diameter, $\mathrm{C}-$ cyst, $G C$ - granulosa cells, TIC - theca interna cells, $\times 200$.

the CON group. The expression of $3 \beta$-HSD and $\mathrm{P} 450_{\text {arom }}$ and proteins in the walls of small-sized follicles was similar in both the CON and DXM groups (Fig. 1).

\section{Localization of P450 ${ }_{\text {scc }}, 3 \beta-H S D$ and $P 450_{\text {arom }}$ in the ovarian structures}

\section{Preantral follicles}

The intensity of the immunoreactivity for $\mathrm{P} 450$ scc in the follicular cells of primordial follicles in the CON group was high (Fig. 1A), while faint in the DXM group (Fig. 2B). The granulosa cells in primary follicles in both studied groups and in the secondary follicles of the CON group were $\mathrm{P} 450_{\text {scc }}$-immunonegative, but the granulosa cells in secondary follicles of the DXM-treated gilts displayed faint $\mathrm{P} 450_{\text {scc }}$ staining. In turn, positive reaction for $\mathrm{P} 450_{\text {arom }}$ was not observed in the cells of primordial, primary and secondary follicles in both studied groups. These follicles in the CON group were also $3 \beta$-HSD-immunonegative, while in the DXMtreated gilts displayed faint $3 \beta-$ HSD staining.

\section{Antral follicles}

$\mathbf{P 4 5 0}_{\text {scc }}$ The granulosa cells of tertiary follicles measuring up to $3 \mathrm{~mm}$ in diameter showed faint $\mathrm{P} 450_{\mathrm{scc}}$ reaction in the CON group, but staining of these cells was absent in the DXM-treated gonads. In contrast, the intensity of the immunoreaction for this enzyme in the theca interna cells of tertiary follicles measuring up to $3 \mathrm{~mm}$ in diameter of the control animals was high and strong in the DXM group. The granulosa and theca interna cells (Fig. 2C) of tertiary follicles measuring 4$6 \mathrm{~mm}$ in diameter in the $\mathrm{CON}$ group showed faint and high reactivity for $\mathrm{P} 450_{\mathrm{scc}}$, respectively. In the cysts, this enzyme staining was high in the granulosa cells and strong in the theca interna cells (Fig. 2D).

3ß-HSD. In both examined group, the granulosa cells of tertiary follicles measuring up to $3 \mathrm{~mm}$ in diameter 
Table 2. Localization and intensity of reaction for $\mathrm{P} 450_{\mathrm{scc}}, 3 \beta$-HSD and $\mathrm{P} 450_{\text {arom }}$ in the ovaries of control gilts (group CON) and animals after DXM injections (group DXM).

\begin{tabular}{|c|c|c|c|c|c|c|c|}
\hline \multirow{2}{*}{\multicolumn{2}{|c|}{ Ovarian structures }} & \multicolumn{2}{|c|}{$\mathrm{P} 450_{\mathrm{sec}}$} & \multicolumn{2}{|c|}{$3 \beta$-HSD } & \multicolumn{2}{|c|}{$\mathrm{P} 450_{\text {arom }}$} \\
\hline & & $\mathrm{CON}$ & DXM & $\mathrm{CON}$ & DXM & $\mathrm{CON}$ & DXM \\
\hline \multicolumn{2}{|c|}{$\begin{array}{l}\text { Primordial follicles } \\
\text { Follicular cells }\end{array}$} & ++ & + & - & + & - & - \\
\hline \multicolumn{2}{|c|}{$\begin{array}{l}\text { Primary follicles } \\
\text { Gramulosa cells }\end{array}$} & - & - & - & + & - & - \\
\hline \multicolumn{2}{|c|}{$\begin{array}{l}\text { Secondary follicles } \\
\text { Gramulosa cells }\end{array}$} & - & + & - & + & - & - \\
\hline \multirow{2}{*}{$\begin{array}{l}\text { Tertiary } \\
\text { follicles }\end{array}$} & $\begin{array}{l}\text { to } 3 \mathrm{~mm} \text { in diameter } \\
\text { Granulosa cells } \\
\text { Theca interna cells }\end{array}$ & $\begin{array}{l}+ \\
++\end{array}$ & $\begin{array}{c}- \\
+++\end{array}$ & $\begin{array}{l}- \\
+\end{array}$ & $\begin{array}{l}- \\
+\end{array}$ & $\begin{array}{l}+ \\
+\end{array}$ & $\begin{array}{l}++ \\
+\end{array}$ \\
\hline & $\begin{array}{l}\text { 4-6 mm in diameter } \\
\text { Granulosa cells } \\
\text { Theca interna cells }\end{array}$ & $\begin{array}{l}+ \\
++\end{array}$ & 1.s. & $\begin{array}{l}- \\
+\end{array}$ & 1.s. & $\begin{array}{l}++ \\
+\end{array}$ & l.s. \\
\hline \multicolumn{2}{|c|}{$\begin{array}{l}\text { Cysts } \\
\text { Granulosa layer } \\
\text { Theca interna cells }\end{array}$} & 1.s. & $\begin{array}{c}++ \\
+++ \\
\end{array}$ & l.s. & $\begin{array}{l}++ \\
+ \\
\end{array}$ & 1.s. & $\begin{array}{l}+++ \\
+++ \\
\end{array}$ \\
\hline \multicolumn{2}{|c|}{ Corpora lutea } & +++ & 1.s. & + & 1.s. & + & 1.s. \\
\hline
\end{tabular}

$(-)$ - the lack of staining, +- faint, ++- high, +++- strong; 1.s. - the lack of structure

were $3 \beta$-HSD-immunonegative, while the theca inter$n a$ cells of these follicles were faintly stained. Similar results were found in tertiary follicles measuring 4-6 $\mathrm{mm}$ in diameter in the CON group. The granulosa and theca interna layers of cyst showed high (Fig. 2H) and faint immunoractivity for $3 \beta-\mathrm{HSD}$, respectively.

$\mathbf{P 4 5 0}_{\text {arom. }}$ The granulosa and theca interna cells of tertiary follicles measuring up to $3 \mathrm{~mm}$ in diameter in the CON group were faintly stained for $\mathrm{P} 450_{\text {arom }}$ (Fig. 2I). In the DXM group, the granulosa and theca interna cells in these follicles displayed high and faint P450 arom expression (Fig. 2J), respectively. Similar intensity of the reaction displayed the granulosa (Fig. $2 \mathrm{~K}$ ) and theca interna cells of tertiary follicles measuring 4-6 $\mathrm{mm}$ in diameter in the CON group. The P450 arom staining in the granulosa (Fig. 2L) and theca interna layers of cyst was strong.

\section{Corpora lutea}

In the steroidogenic cells of CL in the CON group, the intensity of immunoreactivity for $\mathrm{P} 450_{\text {scc }}$ was strong, while it was faint for $3 \beta$-HSD and $\mathrm{P} 450$ arom.

\section{Discussion}

The present study provides the detailed description of the expression patterns of $\mathrm{P} 450_{\mathrm{scc}}, 3 \beta$-HSD and $\mathrm{P} 450_{\text {arom }}$ proteins in the porcine cystic ovaries. Macroscopic examination of the ovaries, conducted on day
26 of the study (expected 11 day of the second studied cycle), revealed that i.m. DXM injections on days 7-21 of the first estrous cycle in the gilts lead to development of cystic status of the ovaries. The weight, length and height of the pathologically changed ovaries were diminished, what may results from the presence of partially luteinized follicular cysts, the reduction in the number of small ovarian follicles (1-3 $\mathrm{mm}$ in diameter) and a total lack of both the medium-sized follicles and CL. Similar results were previously found in the pigs after adrenocorticotropic hormone (ACTH) or DXM treatment $[9,11,20,21]$.

In the present study, administration of DXM resulted in an increase in the level of $\mathrm{P}^{4} 50_{\mathrm{scc}}$ and $3 \beta$-HSD protein in the walls of cysts, and $\mathrm{P} 450_{\mathrm{scc}}$ also in the walls of small-sized follicles. These observations are in the line with results of our earlier experiment, in which the ovaries were collected on day 20 of the second studied cycle from DXM-treated gilts, receiving this hormone from day 16 of the first studied estrous cycle until day 9 of the second studied cycle [9]. Moreover, in the present study we have found that the expression of $\mathrm{P} 450_{\text {arom }}$ proteins in the cyst walls increased, while the level of this enzyme, as well as of $3 \beta$-HSD did not change significantly in the small follicles in the DXM group. These results, however, differ from these found in cystic ovaries obtained on day 20 of the second studied cycle from gilts receiving DXM earlier [9]. These differences may be attributable to the phase of the estrous cycle, in which the admin- 
istration of cyst-induced DXM was started and can also result from day of the estrous cycle when the ovaries were collected.

It is difficult to explain why the expression of $\mathrm{P} 450_{\text {scc }}, 3 \beta$-HSD and $\mathrm{P} 450_{\text {arom }}$ proteins increases in the structures (cysts and/or small follicles) of cystic ovaries. It is however possible to speculate that changes in the expression of these enzymes may be a consequence of the action of (largely unknown) intragonadal factors. One of possible factors leading to an increase in $\mathrm{P} 450_{\mathrm{scc}}$ and $3 \beta$-HSD expression in the cysts and/or small follicles found in DXM-treated gonads could be a marked increase in the neuronal input to these structures. It has namely been found that the number of dopamine- $\beta$-hydroxylase and/or neuropeptide tyrosine (NPY) immunoreactive (IR) or vasoactive intestinal polypeptide (VIP)-IR nerve fibers was distinctly higher in the vicinity of these structures. Moreover, a simultaneous increase in the amount of noradrenaline (NA), adrenaline and $\mathrm{P}_{4}$ in wall of these structures was also stated (unpublished data). Similar phenomenon has previously been observed by us in the cystic porcine ovaries [9]. It had been previously reported that NA stimulated $\mathrm{P} 450_{\mathrm{scc}}$ and $3 \beta$-HSD activity in bovine luteal cells [22] while VIP induced the synthesis of the $\mathrm{P} 450_{\text {scc }}$ complex in rat granulosa cells [23]. In turn, there is a lack of data concerning the effect of neurotransmitter on the expression of $\mathrm{P} 450_{\text {arom }}$ in the ovarian structures. It was only earlier found that VIP is able to enhance P450 arom activity [24] and the level of the mRNA encoding this enzyme in rat granulosa cells [25]. However, the increased expression of $\mathrm{P} 450_{\mathrm{scc}}$, observed in the structures of the cystic ovaries may also be a consequence of the DXM treatment. This assumption is supported by Yang et al. [26], who have presented that DXM increased folliclestimulating hormone-stimulated $\mathrm{P} 450_{\text {scc }}$ mRNA level in the porcine granulosa cells. However, there is a lack of data dealing with the influence of glucocorticoids on $3 \beta$-HSD and $\mathrm{P} 450_{\text {arom }}$ expression in ovarian cells. Up to now it was only reported that the activity of $\mathrm{P} 450_{\text {arom }}$ in granulosa cells is suppressed by DXM and ACTH $[21,27]$.

Light-microscopic observation showed that the cellular localization of $\mathrm{P} 450_{\text {scc }}, 3 \beta$-HSD and $\mathrm{P} 450_{\text {arom }}$ in steroidogenic cells of follicles and CL in the control group is in agreement with results of previous studies performed on ovaries of gilts and goats, with exception of the presence of P450 arom in cells of CL [28-33]. In turn, the distribution of studied enzymes in the structures of cystic ovaries has changed. After DXM treatment, faint $\mathrm{P} 450_{\text {scc }}$-immunoreactivity was visible in the cells of secondary follicles and for $3 \beta$-HSD in the primordial, primary and secondary follicles, while labelling for these enzymes was absent from control gonads. The explanation of this phenomenon is diffi- cult because in the available literature, there is a complete lack of data concerning the expression of the examined enzymes in the preantral follicles in cystic ovaries. As it was mentioned above, the occurrence of $\mathrm{P} 450_{\text {scc }}$ and $3 \beta$-HSD in the follicles of the cystic gonads may be the result of DXM treatment [26]. Moreover, the presence of numerous nerve fibers containing NPY, vesicular acetylcholine transporter and/or neuronal nitric oxide synthase (unpublished data) around the secondary follicles allow to suppose that NPY, acetylcholine and nitric oxide may also effect the expression of $\mathrm{P}^{4} 50_{\mathrm{scc}}$ and $3 \beta$-HSD in these follicles. In contrast, the decrease in the intensity of $\mathrm{P} 450_{\text {scc }}$ staining, in the primordial follicles, as well as the lack of this enzyme in granulosa cells of follicles with the diameter up to $3 \mathrm{~mm}$, observed in the DXM-treated gilts, could be probably a consequence of derangement in maturation of these follicles evoked by DXM [34]. Thus, appearance of $\mathrm{P} 450_{\mathrm{scc}}$ and $3 \beta$-HSD proteins in preantral follicles of the cystic ovaries may suggest steroidogenic activity of these structures.

Furthermore, we also found the presence of $3 \beta$ HSD in granulosa layers of the cysts, while the immunoreactivity of this enzyme was absent in granulosa cells of medium follicles in the control ovaries. However, the $3 \beta$-HSD staining in theca interna cells of cysts and above-mentioned follicles was similar. These results are in agreement with findings of Calder et al. [35] who reported 33-HSD mRNA expression in the bovine granulosa and theca interna layers of cysts. However, Kaaijk et al. [6] have shown the presence of $3 \beta-\mathrm{HSD}$ only in the follicular theca interna cells of polycystic ovaries of women. Most probably, the presence of $3 \beta$-HSD-immunoreactivity in the granulosa layer of cysts may be the consequence of the luteinization of granulosa cells, what has previously been suggested in women with the polycystic ovary syndrome [36]. Moreover, in our experiment the granulosa and theca interna layers of cysts demonstrated $\mathrm{P} 450_{\text {scc }}$ and $\mathrm{P} 450_{\text {arom }}$ staining, which was significantly higher than in the follicles $4-6 \mathrm{~mm}$ in diameter of control animals. The positive reaction for $\mathrm{P} 450_{\text {scc }}$ and $\mathrm{P} 450_{\text {arom }}$ was also observed in both granulosa and theca interna layers of small follicles (with exception of the presence of $\mathrm{P}^{4} 50_{\mathrm{scc}}$ in granulosa cells of the CON group) in all animals, but the intensity of immunolabelling to $\mathrm{P}^{4} 50_{\mathrm{scc}}$ in theca interna cells, and to $\mathrm{P} 450_{\text {arom }}$ in granulosa cells was stronger after DXM treatment. Similar localization of $\mathrm{P} 450_{\mathrm{scc}}$ was described earlier in the follicular structures from polycystic ovaries of women [6], whereas in cows the $\mathrm{P} 450_{\text {scc }}$ reaction was presented only in the theca inter$n a$ cells of cysts [8]. However, the higher intensity of the immunoreaction for $\mathrm{P} 450_{\mathrm{scc}}$ in the theca interna layer of cysts and follicles is in line with Jakimiuk et al. [36] earlier study where they have found an 
increase in the $\mathrm{P} 450_{\mathrm{scc}}$ mRNA expression in the theca interna cells of follicles in the women with COD. Appearance of $3 \beta$-HSD protein in the granulosa layer of the cysts, observed in the present study after DXM injections, as well as the increased intensity of the labelling towards $\mathrm{P} 450_{\mathrm{scc}}$ in the two theca layers of cysts and theca interna cells of follicles measuring up to $3 \mathrm{~mm}$ in diameter, suggest that an up-regulated synthesis of $\mathrm{P}_{4}$ may take place in these cells. On the other hand, the observed increase in the immunoexpression of $\mathrm{P} 450_{\text {arom }}$ in the theca interna cells (with exception of the presence of $\mathrm{P} 450_{\text {arom }}$ in theca interna cells of small follicles in the DXM group) and also in the granulosa layer of above-listed structures, suggest a simultaneous up-regulation in the production of estrogen in the cystic ovaries.

In conclusion, the present study clearly show that in porcine ovaries with polycystic status, induced by DXM injections on days 7-21 of the estrous cycle, the expression and localization patterns of $\mathrm{P} 450_{\mathrm{scc}}, 3 \beta$ HSD and $\mathrm{P} 450_{\text {arom }}$ were changed. Moreover, these results may suggest also that these enzymes, trough the control of ovarian steroidogenesis, may play an essential role in the formation and/or course of cystic ovarian disease.

Acknowledgements: We would like to thank Dr. N. Rahman from University of Helsinki, Finland, for his kind donation of 3 $\beta-H S D$ antibodies. This work was supported by grant no. 3PO6K00722 from the State Committee for Scientific Research in Poland.

\section{References}

[1] Scholten JA, Liptrap RM. A role for the adrenal cortex in the onset of cystic ovarian follicles in the sow. Can J Comp Med. 1978;42:525-533.

[2] Elliot JI, King GJ, Robinson HA. Reproductive performance of the sow subsequent to weaning piglets at birth. Can $J$ Comp Med. 1980;60:65-71.

[ 3] Stoebel DP, Moberg GP. Repeated acute stress during the follicular phase and luteinizing hormone surge of dairy heifers. J Dairy Sci. 1982;65:92-96.

[ 4] Boryczko Z, Bostedt H, Hoffmann B. Comparison of the hormonal and chemical composition of the fluid from bovine ovarian follicles and cysts. Reprod Domest Anim. 1995;30:3638.

[ 5] Takayama K, Fukaya T, Sasano H, et al. Immunohistochemical study of steroidogenesis and cell proliferation in polycystic ovarian syndrome. Hum Reprod. 1996;11:1387-1392.

[ 6] Kaaijk EM, Sasano H, Suzuki T, Beek JF, van Der Veen F. Distribution of steroidogenic enzymes involved in androgen synthesis in polycystic ovaries: an immunohistochemical study. Mol Hum Reprod. 2000;6:443-447.

[7] Cooke GM, Brawer JR, Farookhi R. Steroidogenic enzyme activities in rat polycystic ovaries. Can J Physiol Pharmacol. 1993; 71:247-253.

[ 8] Isobe N, Nakao T, Yoshimura Y. Distribution of cytochrome P450-side chain cleavage in the theca interna layers of bovine small antral and cystic follicles. Reprod Domest Anim. 2003; 38:405-409.

[9] Jana B, Dzienis A, Rogozińska A, et al. Dexamethasoneinduced changes in sympathetic innervation of porcine ovaries and in their steroidogenic activity. $J$ Reprod Dev. 2005;6:715-725.

[10] Peter AT, Liptrap RM. Plasma gonadotrophin levels in sows with experimental cystic ovarian follicles. British Vet J. 1985; 141:288-296.

[11] Frautschy SA, Liptrap RM. Anovulation and plasma hormone concentrations after administration of dexamethasone during the middle of the luteal phase in sows undergoing estrous cycles. Am J Vet Res. 1988;49:1270-1275.

[12] Cook DL, Smith CA Parfet JR, Youngquist RS, Brown EM, Garverick HA. Fate and turnover rate of ovarian follicular cysts in dairy cattle. J Reprod Fertil. 1990;90:37-46.

[13] Nalbandov AV. Anatomic and endocrine causes of sterility in female swine. Fertil Steril. 1952;3:100-114.

[14] Jana B, Kozłowska A, Andronowska A, Jedlińska-Krakowska $M$. The effect of tumor necrosis factor- $\beta$ (TNF- $\beta$ ), interleukin (IL)- 1 and IL-6 on chorioamnion secretion of prostaglandins (PG)F2 $\beta$ and E2 in pigs. Rep Biol. 2008;8:57-68.

[15] Bradford MM. A rapid and sensitive method for the quantitation of microgram quantities of protein utilizing the principle of protein-dye binding. Anal Biochem. 1976,72:248-254.

[16] Coons AH. Fluorescent antibody methods. General Cytochem Methods. 1958;1:399-422.

[17] Greenwald GS, Moor RM. Isolation and preliminary characterization of pig primordial follicles. J Reprod Fertil. 1989; 87:561-571.

[18] Wulff C, Wilson H, Wiegand SJ, Rudge JS, Fraser HM. Prevention of thecal angiogenesis, antral follicular growth, and ovulation in the primate by treatment with vascular endothelial growth factor trap R1R2. Endocrinology. 2002; 143:2797-2807.

[19] Levanti MB, German $\alpha$ A, Abbate F, Montalbano G, Vega JA, German $\alpha$ G. TrkA and p75NTR in the ovary of adult cow and pig. J Anat. 2005;207:93-96.

[20] Ogasa A, Domeki I, Itoh S, Tsutsui T, Kawakami E. The formation of cystic ovarian follicles in the sows after treatment with ACTH. Jpn J Zootech Sci. 1988;59:1004-1012.

[21] Ryan PL, Raeside JI. Steroidogenesis in granulosa cells after the induction of large cystic follicles with adrenocortycotropin $(\mathrm{ACTH})$ in the cyclic gilt. In: Proceedings of 11 th International Congress on Animal Reproduction and Artificial Insemination Dublin Ireland, Abstract, 1988;458.

[22] Kotwica J, Bogacki M, Rękawiecki R. Neural regulation of the bovine corpus luteum. Domest Anim Endocrinol. 2002; 23:299-308.

[23] Trzeciak WH, Ahmed CE, Simpson ER, Ojeda SR. Vasoactive intestinal peptide induces the synthesis of the cholesterol side-chain cleavage enzyme complex in cultures rat ovarian granulosa cells. Proc Natl Acad Sci. 1986;83:7490-7494.

[24] George FW, Ojeda SR. Vasoactive intestinal peptide enhances aromatase activity in the neonatal rat ovary before development of primary follicles or responsiveness to follicle stimulating hormone. Proc Natal Acad Sci. 1987;84:5803-5807.

[25] Mayerhofer A, Dissen GA, Costa ME, Ojeda SR. A role for neurotransmiters in early follicular development: induction of functional follicle-stimulating hormone receptors in newly formed follicles of the rat ovary. Endocrinology. 1997;138: 3320-3329.

[26] Yang JG, Yu CC, Li PS. Dexamethasone enhances follicle stimulating hormone-induced $\mathrm{P} 450_{\mathrm{scc}}$ mRNA expression and progesterone production in pig granulosa cells. Chinese $J$ Physiol. 2001;44:111-119.

[27] Kawate N, Inaba T, Mori J. Changes in plasma concentrations of gonadotropins and steroid hormones during the formation of bovine cysts induced by the administration of ACTH. $J$ Vet Med Sci. 1996;58:141-144.

[28] Lautincik J, Kolodzieyski L, Elias V, Hyttel P, Osawa Y, Sirotkin A. Immunocytochemical localization of aromatase in 
the ovary of superovulated cattle, pigs and sheep. Acta Vet Scand.1994;35:185-191.

[29] Conley AJ, Kaminski MA, Dubowsky SA, Jablonka-Shariff A, Redmer DA, Reynolds LP. Immunohistochemical localization of 3 beta-hydroxysteroid dehydrogenase and P450 17 alpha-hydroxylase during follicular and luteal development in pigs, sheep and cows. Biol Reprod. 1995;52:1081-1094.

[30] Garrett WM, Guthire HD. Steroidogenic enzyme expression during preovulatory follicle maturation in pigs. Biol Reprod. 1996;56:1424-1431.

[31] Shores E, Picton HM, Harada N, Hunter MG. Immunohistochemical localization of steroidogenic enzymes within the porcine follicles. Raport of NOW'97, 1997.

[32] Słomczynska M, Tabarowski Z. Localization of androgen receptor and cytochrome P450 aromatase in the follicle and corpus luteum of the porcine ovary. Anim Reprod Sci. 2001; 65:127-134.

[33] Weng Q, Medan MS, Ren L, Watanabe G, Tsubota T, Taya, K. Immunolocalization of steroidogenic enzymes in the corpus luteum and placenta of the Japanese Shiba goat. J Reprod Dev. 2005;51:247-252.

[34] Gee CM; Geissinger HD, Liptrap RM. Morphometric and steroid hormone changes associated with experimental anovulatory follicles in the sow. Can J Vet Res. 1991;55:206211.

[35] Calder MD, Manikkam M, Salfen BE, et al. Dominant bovine ovarian follicular cysts express increased levels of messenger RNAs for luteinizing hormone receptor and 3 beta-hydroxysteroid dehydrogenase delta (4), delta (5) isomerase compared to normal dominant follicles. Biol Reprod. 2001;65:471-476.

[36] Jakimiuk AJ, Weitsman SR, Navab A, Magoffin DA. Luteinizing hormone receptor, steroidogenesis acute regulatory protein, and steroidogenic enzyme messenger ribonucleic acids are overexpressed in thecal and granulosa cells from polycystic ovaries. J Clin Endocrinol Metab. 2001;86:1318-1323.

Submitted: 8 February, 2009 Accepted after reviews: 13 March, 2009 